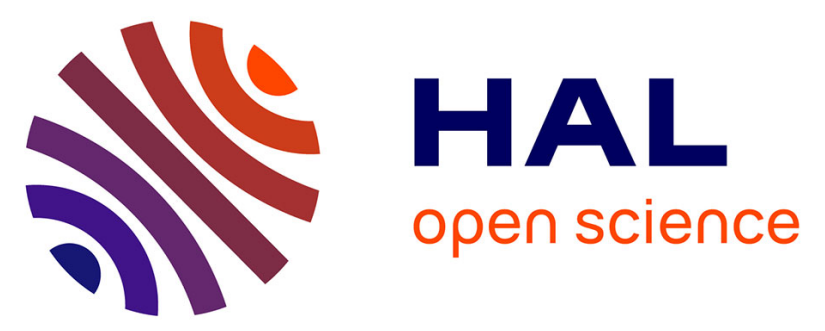

\title{
Lead and Antimony in Basal Ice From Col du Dome (French Alps) Dated With Radiocarbon: A Record of Pollution During Antiquity
}

Susanne Preunkert, Joseph A Mcconnell, Helene Hoffmann, Michel Legrand, Andrew Wilson, Sabine Eckhardt, Andreas Stohl, Nathan Chellman, Monica Arienzo, Ronny Friedrich

\section{To cite this version:}

Susanne Preunkert, Joseph A Mcconnell, Helene Hoffmann, Michel Legrand, Andrew Wilson, et al.. Lead and Antimony in Basal Ice From Col du Dome (French Alps) Dated With Radiocarbon: A Record of Pollution During Antiquity. Geophysical Research Letters, 2019, 46 (9), pp.4953-4961. 10.1029/2019GL082641 . hal-02410052

\section{HAL Id: hal-02410052 https://hal.science/hal-02410052}

Submitted on 10 Nov 2021

HAL is a multi-disciplinary open access archive for the deposit and dissemination of scientific research documents, whether they are published or not. The documents may come from teaching and research institutions in France or abroad, or from public or private research centers.
L'archive ouverte pluridisciplinaire HAL, est destinée au dépôt et à la diffusion de documents scientifiques de niveau recherche, publiés ou non, émanant des établissements d'enseignement et de recherche français ou étrangers, des laboratoires publics ou privés.

$$
\text { Copyright }
$$




\section{Geophysical Research Letters}

\author{
RESEARCH LETTER \\ 10.1029/2019GL082641 \\ Key Points: \\ - Lead and antimony Alpine ice \\ records spanning European \\ antiquity provide evidence of past \\ Roman mining activities \\ - Radiocarbon analysis of $\mathrm{Col} \mathrm{du}$ \\ Dome (Mont Blanc, French Alps) \\ basal glacier ice suggests ice as old as \\ $\sim 5,000 \pm 600$ cal years BP \\ - Comparison between Greenland \\ and Alpine lead ice records \\ consistently shows the effect of \\ Roman mining in proximity to the \\ Alps
}

Supporting Information:

- Supporting Information S1

- Data Set 1

- Data Set 2

Correspondence to:

S. Preunkert,

suzanne.preunkert@univ-grenoble-

alpes.fr

Citation:

Preunkert, S., McConnell, J. R., Hoffmann, H., Legrand, M., Wilson, A. I., Eckhardt, S., et al. (2019). Lead and antimony in basal ice from $\mathrm{Col} \mathrm{du}$ Dome (French Alps) dated with radiocarbon: A record of pollution during antiquity. Geophysical Research Letters, 46, 4953-4961. https://doi.org/ 10.1029/2019GL082641

Received 28 FEB 2019 Accepted 5 APR 2019 Published online 7 MAY 2019

(C)2019. American Geophysical Union. All Rights Reserved.

\section{Lead and Antimony in Basal Ice From Col du Dome (French Alps) Dated With Radiocarbon: A Record of Pollution During Antiquity}

\author{
Susanne Preunkert ${ }^{1} \mathbb{D}$, Joseph R. McConnell ${ }^{2}$ (D), Helene Hoffmann ${ }^{3,4}$ (D), Michel Legrand ${ }^{1}(\mathbb{D}$, \\ Andrew I. Wilson ${ }^{5}$, Sabine Eckhardt ${ }^{6}$ (D), Andreas Stohl ${ }^{6}$ (D), Nathan J. Chellman ${ }^{2}$ (D), \\ Monica M. Arienzo ${ }^{2}$ iD, and Ronny Friedrich ${ }^{7}$ iD \\ ${ }^{1}$ CNRS, Institut des Géosciences de l'Environnement, Université Grenoble Alpes, Grenoble, France, ${ }^{2}$ Division of \\ Hydrologic Sciences, Desert Research Institute, Reno, Nevada, USA, ${ }^{3}$ Institute of Environmental Physics, Heidelberg \\ University, Heidelberg, Germany, ${ }^{4}$ Alfred-Wegener-Institut Helmholtz Zentrum für Polar- und Meeresforschung, \\ Bremerhaven, Germany, ${ }^{5}$ Faculty of Classics, University of Oxford, Oxford, UK, ${ }^{6}$ Department of Atmospheric and Climate \\ Research, Norwegian Institute for Air Research, Kjeller, Norway, ${ }^{7}$ Curt-Engelhorn-Center Archaeometry, Mannheim, \\ Germany
}

\begin{abstract}
Lead and antimony measurements in basal ice from the Col du Dome glacier document heavy metal pollution in western Europe associated with emissions from mining and smelting operations during European antiquity. Radiocarbon dating of the particulate organic carbon fraction in the ice suggests that the basal ice dates to $\sim 5,000 \pm 600$ cal years BP. In agreement with a precisely dated Greenland lead record, the Col du Dome record indicates two periods of significant lead pollution during the Roman period, that is, the last centuries before the Common Era to the second century of the Common Era. Atmospheric modeling and the Col du Dome record consistently show an overall magnitude of the lead perturbation 100 times larger than in the Greenland record. Antimony closely tracked lead, with antimony pollution about 2 orders of magnitude lower, consistent with European peat records.

Plain Language Summary Measurements of radiocarbon on particulate organic matter trapped in ice showed that the deepest ice of the Mont Blanc glacier covers the entire period of antiquity (from $800 \mathrm{BCE}$ to $250 \mathrm{CE}$ ). Lead measurements indicated significant metal pollution during the Roman Republican and the Imperial period, that is, during the last centuries before the Common Era to the second century of the Common Era, with much lower levels before and after. We show that the Roman-era emissions enhanced the natural lead level by at least a factor of 10, which was already significant compared to the modern enhancement by a factor of 100 due to lead emissions related to the use of leaded gasoline. This first ice record of pollution by antimony, another toxic heavy metal, during antiquity showing large Roman-era increases in parallel with lead, confirms that early mining and smelting activities had environmental implications beyond simply lead contamination.
\end{abstract}

\section{Introduction}

Chemical impurities contained in high-elevation, midlatitude glaciers hold detailed information on atmospheric chemistry at regional scales. Because of proximity to European anthropogenic emissions, numerous ice cores from sites located in the Alps have been used to investigate the growing impact of human activities on atmospheric and precipitation chemistry during the last two centuries. While ice cores have been collected from Col du Dome (Mont Blanc massif, CDD), Fiescherhorn (Bernese Alps), Ortles (Eastern Alps), and Colle Gnifetti (Monte Rosa region, CG), most studies have been conducted at CG (4,450 m above sea level; Schwikowski, 2004; Wagenbach et al., 1988, 2012) and CDD (4,250 m above sea level; Preunkert \& Legrand, 2013). For example, Preunkert et al. (2000) exploited the very high surface snow accumulation rates at $\mathrm{CDD}$ ( 0.5 to 2.4 meter water equivalent (mwe) per year) to reconstruct seasonally resolved trends of organic and inorganic chemical compounds related to twentieth-century pollution in Europe (Preunkert \& Legrand, 2013). Because of rapid thinning and complex ice flow within mountain glaciers, particularly at high snow accumulation sites such as CDD, previous long-term investigations extending to the nineteenth century or earlier have been conducted only at the lower snow accumulation CG site (typically $<1$ mwe/year (Haeberli \& Alean, 1985)). Recent developments of radiocarbon analysis methods for 
minute amounts of water-insoluble organic carbon particles (POC) preserved in ice enable for the first time quantitative dating of preindustrial and basal ice, albeit with relatively large uncertainties (Hoffmann et al., 2018; Jenk et al., 2006, 2009; Sigl et al., 2009). For example, radiocarbon analysis of basal ice from two cores drilled to bedrock at CG (53.8 and 62.8 mwe) showed basal ${ }^{14} \mathrm{C}$ ages exceeding 3,900 cal years BP (Hoffmann et al., 2018) and 15,000 cal years BP (Jenk et al., 2009). In spite of the existence of at least two high-elevation European glacier sites permitting investigation of ice from the last millennia, only a few CG ice studies have attempted to investigate possible changes in atmospheric lead emissions from mining and smelting activities during the early Middle Ages (Gabrieli \& Barbante, 2014; Loveluck et al., 2018) and following the Black Death pandemic (More et al., 2017).

In addition to numerous European peat bog and lake sediment records (e.g., Bindler, 2018; Brännvall et al., 2001; Thevenon et al., 2011), until now only Greenland ice documented lead pollution since antiquity. The pioneering study conducted by Rosman et al. (1997) on a limited number of discrete Greenland ice samples has been recently followed by a far more continuous and precisely dated record extracted from North Greenland Ice Core Project 2 (NGRIP2) ice samples (McConnell et al., 2018). There is, however, a gap between such very remote Greenland ice records and more local terrestrial and lacustrine European archives.

Here we establish a deep-ice chronology based largely on the first radiocarbon measurements from the CDD site, thereby enabling investigation of heavy-metal pollution in the French Alps from mining and smelting operations during European antiquity. We used detailed measurements of lead and antimony in CDD icespecifically samples from a 123.68-m core drilled to bedrock in 2004-as well as state-of-the-art FLEXPART atmospheric aerosol transport and deposition modeling (Stohl et al., 2005) for the interpretation. We also compare the unique lead CDD alpine record covering the antiquity with the Greenland NGRIP2 ice record as well European peat bog and lake sediment records.

\section{Sampling and Analysis}

\subsection{Trace Metal Analysis}

Archived samples from two CDD ice cores (referred to as C10, CDK; Legrand et al., 2013), drilled at virtually the same place in 1994 and 2004, were analyzed for a broad range of elements and chemical species using the continuous flow ice core analytical system at the Desert Research Institute Ultra Trace Chemistry Laboratory (Legrand et al., 2018). Here we focus on the deepest $10 \mathrm{~m}$ of the CDK core (i.e., from 85.3 to $95.15 \mathrm{mwe}$ ). Due to the presence of entrained sediment from the bed, the deepest section (CDK-183 sample, length 0.50 mwe) was not analyzed. Longitudinal samples $(3.3 \times 3.3-\mathrm{cm}$ cross section $)$ were melted sequentially on a heated ceramic melter head and the meltwater stream split into three regions by ridges engraved in the melter head. Lead $(\mathrm{Pb})$ and coanalyzed species such as antimony $(\mathrm{Sb})$ and cerium $(\mathrm{Ce})$ were measured in the meltwater from the innermost ring (10\% of the sample cross section) using two inductively coupled plasma-mass spectrometers (Thermo Scientific Element 2 high-resolution with concentric Teflon ${ }^{\mathrm{TM}}$ nebulizer [electrospray ionization]; Maselli et al., 2017). The detection limits defined as 3 times the standard deviation of the blank were $0.0004 \mathrm{ng} / \mathrm{g}$ for $\mathrm{Pb}, 0.0003 \mathrm{ng} / \mathrm{g}$ for Ce, and $0.0001 \mathrm{ng} / \mathrm{g}$ for Sb. Assessment of measurement recovery during continuous measurements with the Desert Research Institute analytical system indicated that recovery was $\sim 100 \%$ for $\mathrm{Pb}$ and $\mathrm{Sb}$, and $60 \%$ for Ce. Therefore, measured Ce concentrations were scaled by a factor of 1.7 to correct for underrecovery (McConnell et al., 2007, 2018); no correction for $\mathrm{Pb}$ and $\mathrm{Sb}$ was necessary. To calculate the noncrustal fractions ( $\mathrm{ncPb}$ and $\mathrm{ncSb}$ ) and enrichment factors $\left(\mathrm{Pb}-\mathrm{EF}_{\mathrm{Ce}}\right.$ and $\left.\mathrm{Sb}-\mathrm{EF}_{\mathrm{Ce}}\right)$, we used the "mean sediment" $\mathrm{Pb} / \mathrm{Ce}$ ratio of 0.23 and $\mathrm{Sb} / \mathrm{Ce}$ of 0.0144 , respectively (Bowen, 1966). As discussed in Text S1 in the supporting information, the use of the "mean sediment" $\mathrm{Sb} / \mathrm{Ce}$ ratio (0.0144) resulted in some negative $\mathrm{ncSb}$ values and $\mathrm{Sb}-\mathrm{EF}_{\mathrm{Ce}}$ ratios less than unity. We therefore assumed a $\mathrm{Sb} / \mathrm{Ce}$ ratio of 0.005 , which is intermediate between "mean crustal" and "mean sediment" $\mathrm{Sb} / \mathrm{Ce}$ ratios of 0.0029 and 0.0144 (Bowen, 1966).

We used annual layer counting to date the upper sections of both cores, with the layers identified primarily using pronounced seasonal variations in ammonium concentrations. The resulting chronology for the midtwentieth to late twentieth century was in excellent agreement with dating of the C10 core based on prior, more limited chemical measurements (Legrand et al., 2013; Preunkert et al., 2000). A reevaluation of the $\mathrm{C} 10$ chronology based on the new continuous measurements of heavy metals, as well as comparisons to well-dated Greenland records (McConnell \& Edwards, 2008), resulted in a revised C10 chronology 
(Legrand et al., 2018). Distinct increases in thallium, lead, and cadmium well documented in Greenland ice in $1890 \mathrm{CE}$ associated with the start of widespread coal burning during the Industrial Revolution also were found in the CDK core at $117.8 \mathrm{~m}$ (90.5 mwe) and used to constrain a revised annual layer count in the early twentieth-century part of the CDK record. Prior to $1890 \mathrm{CE}$, the continuous measurements indicated that no winter snow was preserved, consistent with understanding of upstream deposition processes. To develop a chronology for the basal ice, the ${ }^{14} \mathrm{C}$ content of water-insoluble organic carbon particles $\left(\mathrm{PO}^{14} \mathrm{C}\right)$ was measured in the $5 \mathrm{~m}$ of the CDK core below $117.8 \mathrm{~m}$.

\subsection{The ${ }^{14} \mathrm{C}$ Analysis}

Six samples were taken for $\mathrm{PO}^{14} \mathrm{C}$ analysis. Given the implicit trade-off between sample mass, detection limits and uncertainties of the analytical system, and the time interval covered by each sample, ice with $14-\mathrm{cm}^{2}$ cross section was cut into 35- to 45-cm lengths, resulting in initial ice sample masses of 400-670 g. After decontamination following procedures described in Hoffmann et al. (2018), ice available for $\mathrm{PO}^{14} \mathrm{C}$ analysis was reduced to 215-365 g, with each sample containing POC masses of 2.6 to $8.1 \mu \mathrm{g}$ C (Table S1 in the supporting information).

Radiocarbon sample preparations were performed at the Institute of Environmental Physics (Heidelberg, Germany) with the inline filtration-oxidation-unit REFILOX (Reinigungs-Filtrations-Oxidationssystem) and radiocarbon analysis at the accelerator mass spectrometer facility of the Curt-Engelhorn-Center Archaeometry in Mannheim, Germany (Hoffmann et al., 2017). POC trapped in the ice matrix was filtered, combusted at $340{ }^{\circ} \mathrm{C}$, and analyzed for its ${ }^{14} \mathrm{C}$ content as described by Hoffmann et al. (2018). Calibration of the single ${ }^{14} \mathrm{C}$ ages was performed using the IntCal13 atmospheric curve (Reimer et al., 2013) and OxCal 4.3 (Bronk Ramsey, 1995). Recently, the $\mathrm{CO}_{2}$ collection setup was extended to facilitate sample pooling. This allowed us to directly determine the $\mathrm{F}^{14} \mathrm{C}$ on blanks which previously had to be estimated due to insufficient $\mathrm{CO}_{2}$ yield for AMS measurement (Hoffmann et al., 2018).

This value $(0.71 \pm 0.07$ obtained on three blanks, each consisting of four pooled ultrapure water samples) is in agreement with $\mathrm{F}^{14} \mathrm{C}$ blank values in previous ice studies (as reviewed and adopted in Hoffmann et al., 2018). In Table $\mathrm{S} 1$ in the supporting information, we report ice-sample data corrected for the mean blank $\mathrm{F}^{14} \mathrm{C}$ value as well as the mean POC blank mass of $0.2 \pm 0.1 \mu \mathrm{g}$, which was determined during the course of CDK sample measurements.

Assuming a mass-related mean combustion efficiency of the device of 0.7 (Hoffmann et al., 2018), the POC concentrations obtained by combustion at $340{ }^{\circ} \mathrm{C}$ were $11 \pm 3 \mathrm{ng} \mathrm{C} / \mathrm{g}$ in the three upper samples and $36 \pm 2 \mathrm{ng} \mathrm{C} / \mathrm{g}$ below 93 mwe.

The POC value of the upper three samples is in good agreement with the values observed by Hoffmann et al. (2018) in the $340{ }^{\circ} \mathrm{C} \mathrm{POC}$ fraction at CG, that is, $14 \pm 6 \mathrm{ng} \mathrm{C} / \mathrm{g}$ for ice located more than $3 \mathrm{~m}$ above bedrock. The increased values in CDK samples located below 93 mwe very likely were caused by proximity to the bedrock as also observed at CG (Hoffmann et al., 2018; Jenk et al., 2009). Since similar preindustrial OC levels were observed for CG and CDD (Legrand et al., 2007), we thus exclude significant age errors due to a POC contamination during ${ }^{14} \mathrm{C}$ sample preparation and analysis.

\section{Age of the CDK Basal Ice}

$\mathrm{PO}^{14} \mathrm{C}$ measurements suggest that the $\mathrm{CDK}$ ice core extends to $\sim 5,000 \pm 600$ cal years $\mathrm{BP}$ (Figure 1 ). This is consistent with basal ice ages found at other Alpine sites, that is, 4,000 cal years BP (Hoffmann et al., 2018) and $>10,000$ cal years BP (Jenk et al., 2009) for two CG ice cores, and 7,000 cal years BP for Mount Ortles (3,905 $\mathrm{m}$ above sea level; Gabrielli et al., 2016). The $\mathrm{CDK}$ ice layer ages obtained from the $\mathrm{PO}^{14} \mathrm{C}$ measurements do not increase monotonically with depth as would be expected from well-behaved ice flow. The $1890 \mathrm{CE}$ date derived from annual layer counting at 88.0 mwe lies within the uncertainty range of the radiocarbon age of the $\mathrm{CDK}-173$ sample located at $90.74 \pm 0.21$ mwe. However, the age of the next ${ }^{14} \mathrm{C}$ sample (CDK-176) is $\sim 1,000 \pm 700$ cal years BP (at $68.2 \%$ probability), which appears too old compared to the deeper samples. Similar nonmonotonic age increases with depth were observed previously at CG (Hoffmann et al., 2018; Sigl et al., 2009). Whereas Sigl et al. (2009) suggested possible contamination of ${ }^{14} \mathrm{C}$ samples to explain such outliers at their CG drilling location, Hoffmann et al. (2018) showed for their 


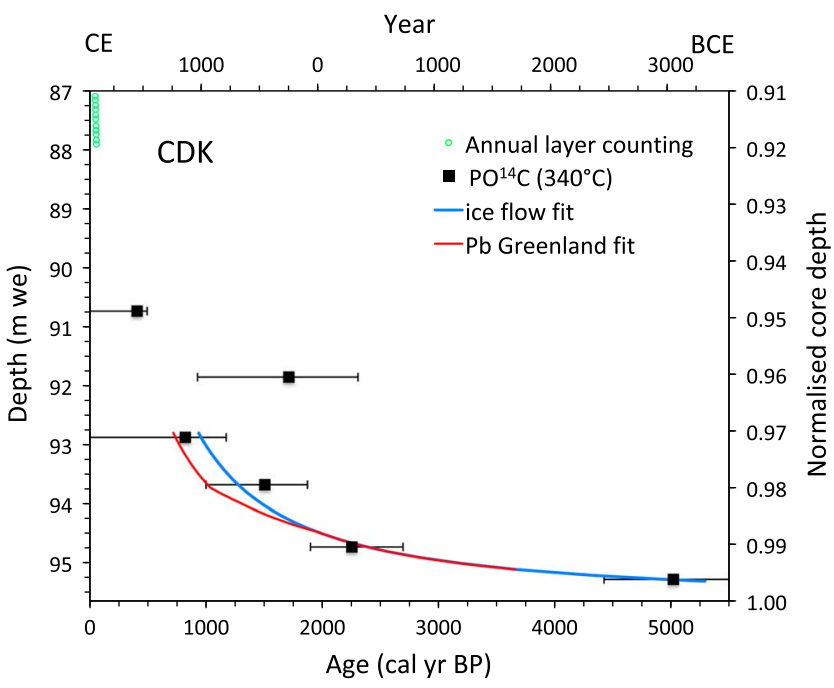

Figure 1. Mean blank corrected and calibrated ${ }^{14} \mathrm{C}$ ages of the six CDK samples with $1 \sigma$ age ranges (Table S1) as error bars. The blue and red lines show the chronologies from the two-parameter fit (Text S2 in the supporting information) and after adjustment to align early Middle Age lead increases in CDD and Greenland ice (Figure 2a). The green circles denote the oldest part of the dating derived from annual layer counting. core position that such age outliers also could result from discontinuities in glacier flow. Slight contamination of the CDK-176 sample cannot be excluded given that the POC level of $14 \mathrm{ng} \mathrm{C/g}$ was somewhat enhanced compared to the samples above and below. On the other hand, a discontinuity in glacier flow also is plausible, since compared to the CG drill site investigated by Hoffmann et al. (2018), the CDK site has an $\sim 10$ and $~ 5$ times higher surface accumulation and horizontal velocity (Lüthi \& Funk, 2000; Vincent et al., 1997), respectively, while the glacier thickness is only 2 times larger. Note also that a temporal discontinuity of 15 years, probably because of an upstream crevasse, was detected previously in the CDK core between 64 and 69 mwe (Legrand et al., 2013). In the following we focus therefore on the deepest CDK ice layers located below 92.9 mwe for which the $\mathrm{PO}^{14} \mathrm{C}$ measurements suggest a monotonic ice age increase with depth.

The CDK basal ice (the last 2.7 mwe) spans the period $\sim 5,000$ to $\sim 1,000$ cal years BP or $\sim 3050 \mathrm{BCE}$ to $950 \mathrm{CE}$ (Table S1 in the supporting information), potentially recording atmospheric heavy-metal pollution from European mining and smelting activities during the antiquity. Initial comparison (Figure $2 \mathrm{a}$ ) of the precisely dated ( \pm 2 years) NGRIP2 record with the CDK lead record using the chronology based on a two-parameter fit to the ${ }^{14} \mathrm{C}$ ages (Figure 1 and Text $\mathrm{S} 2$ in the supporting information) showed that whereas the double peaks in lead pollution observed in Greenland corresponding to the early to mid-Roman Republic (third through first century BCE) and the Roman Empire (first through fifth century CE) were well reproduced in CDK, lead concentrations in the early Middle Ages appeared to increase 250 years earlier. Numerous peat bogs and one CG ice long-term record of European lead pollution during the Middle Ages show increases starting 800 CE (Figures S1 and S2a in the supporting information), consistent with the history of mining during the Middle Ages (Blanchard, 2001), so we adjusted the medieval increase of the fit accordingly, by linearly extending its time scale from $1 \mathrm{CE}$ to $~ 780 \mathrm{CE}$ (i.e., the early medieval maximum), and to match the decrease to $1055 \mathrm{CE}$ evident in the Greenland lead pollution record. This adjustment was well within the $68.2 \%$ uncertainty range in the initial CDK chronology (Figure 1), and it had minimal impact (a shift of 30 years of the second lead pollution peak, assigned now to $120 \mathrm{CE}$; Figure 2) on the chronology during classical antiquity. Note however that the apparently good agreement observed between Greenland and Alpine records for the double peak of Roman pollution does not mean that the reconstructed CDK chronology is exact. For instance, the first lead peak is potentially $~ 110$ years too old, as suggested by the comparison to a nearby Alpine lake sediment record (Figure S1a in the supporting information), which is still consistent with ${ }^{14} \mathrm{C}$ age uncertainties.

\section{The Lead Record in the CDK Basal Ice}

The lead record in the CDK basal ice (3050 BCE to $950 \mathrm{CE}$ ) provides an Alpine ice record of atmospheric pollution from European mining and smelting activities extending from the Bronze Age, through antiquity and into the early Middle Ages. In spite of the existence of several European glacier sites permitting investigation of lead in ice deposited back to the last centuries BCE, none has yet identified lead pollution during antiquity. At CG, only the lead record from More et al. (2017) extends back to $1 \mathrm{CE}$ but discussion was focused on the Black Death pandemic record (1349-1353 CE). As shown in Figure S2b, this CG lead profile reveals evidence neither of a lead decrease at the end of the Roman period, nor of a lead increase at the beginning of the Middle Ages (see Text S3 in the supporting information).

CDD noncrustal $\mathrm{Pb}(\mathrm{ncPb})$ concentrations were low $(\sim 0.015 \mathrm{ng} / \mathrm{g}$; Figure $2 \mathrm{~b})$ at the beginning of classical antiquity and during late antiquity. Enrichment factors $\left(\mathrm{Pb}-\mathrm{EF}_{\mathrm{Ce}}\right)$ of $\sim 3$ with respect to mean sediment (indicated by recovery-corrected cerium concentrations: Text $\mathrm{S} 1$ in the supporting information) during these periods suggest a significant noncrustal contribution (60\% of total lead) that is probably related to natural sources (mainly volcanoes; Nriagu, 1989) or background mining emissions. The upper limit of 

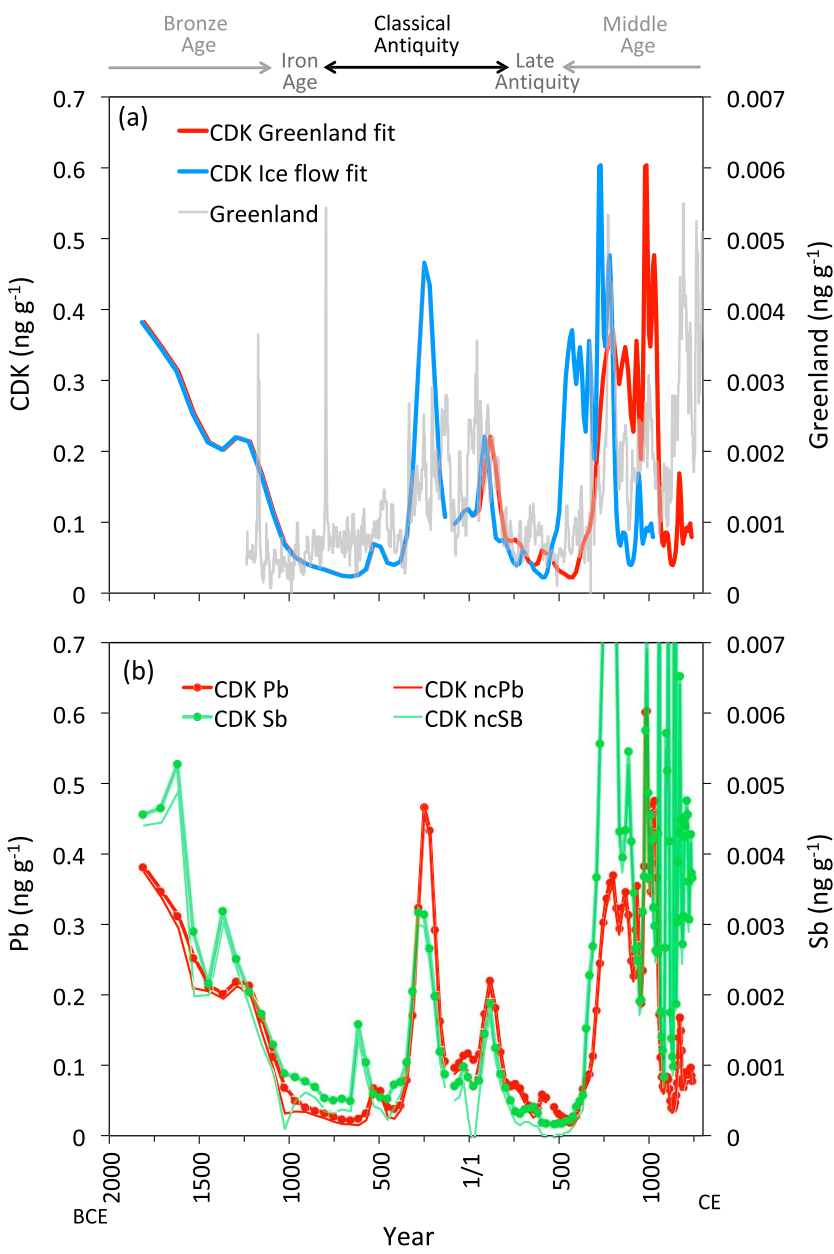

Figure 2. (a) Comparison of the lead concentrations in the Greenland NGRIP2 (grey; McConnell et al., 2018) and Alpine CDK ice cores using two chronologies: blue based on Text S2 in the supporting information, and red after adjustment to align the start of early Middle Age increases in Lead pollution (section 3). (b) Lead and antimony concentrations measured in the CDK ice core. Thick lines and dots show total concentrations. Thin lines show noncrustal contributions (ncPb and ncSb: Text $\mathrm{S} 1$ in the supporting information). nonpollution lead in the CDK core $(\sim 0.015 \mathrm{ng} / \mathrm{g})$ is 150 times lower than typical values $(\sim 2.3 \mathrm{ng} / \mathrm{g})$ observed in modern alpine ice samples during the maximum of late twentieth-century leaded gasoline emissions (Text S3 and Table S2 in the supporting information).

Enrichment factors and noncrust lead concentrations (Figures $2 \mathrm{~b}$ and S3 in the supporting information) clearly show that most of the lead deposited at $\mathrm{CDD}$ is from noncrustal sources. $\mathrm{ncPb}$ concentrations were low from 1000 to $600 \mathrm{BCE}\left(0.024 \pm 0.008 \mathrm{ng} / \mathrm{g} ; \mathrm{Pb}-\mathrm{EF}_{\mathrm{Ce}} 3.4 \pm 1.0\right)$ and from

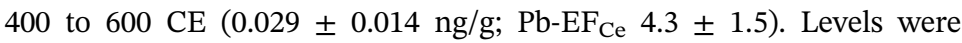
enhanced during two distinct periods during antiquity, with a first maximum of $0.46 \mathrm{ng} / \mathrm{g}\left(\mathrm{Pb}-\mathrm{EF}_{\mathrm{Ce}}\right.$ of 53) in the mid third or more probably the second century $\mathrm{BCE}$, and a second of $0.21 \mathrm{ng} / \mathrm{g}\left(\mathrm{Pb}-\mathrm{EF}_{\mathrm{Ce}}\right.$ of 25.3) around $120 \mathrm{CE}$. Lead levels between the two maxima (130 BCE to $55 \mathrm{CE}$ ) were intermediate $\left(0.09 \pm 0.01 \mathrm{ng} / \mathrm{g} ; \mathrm{Pb}-\mathrm{EF}_{\mathrm{Ce}} 8.0 \pm 3.0\right)$. The overall pattern of the CDK record during antiquity, therefore, is similar to the Greenland record, with enhanced $\mathrm{Pb}$ levels during a period of 500 years interrupted by a period of $\sim 100$ years. As discussed in detail by McConnell et al. (2018), these changes reflect periods of prosperity of the mid-Roman Republic and Imperial periods that were interrupted by wars and the Crisis of the Roman Republic. The Roman-era perturbation in CDD lead levels is larger by 2 orders of magnitude than in Greenland, as expected given the proximity of the Alps to Roman-era mining sites. This relative CDD-to-NGRIP2 difference is consistent with FLEXPART atmospheric aerosol transport and deposition modeling (Text S4 in the supporting information) simulating deposition rates of 1,600 $( \pm 330) \mu \mathrm{g}$ $\mathrm{m}^{-2} \mathrm{yr}^{-1}$ at CDD and $13( \pm 6) \mu \mathrm{g} \mathrm{m}^{-2} \mathrm{yr}^{-1}$ at NGRIP2 (Figure 3) for a $1-\mathrm{kg} / \mathrm{s}$ lead emission rate located near the Rio Tinto mining complex in southern Spain. Note also that the Roman-era lead perturbation at CDD $(0.3 \mathrm{ng} / \mathrm{g})$ was 8 times lower than the modern increase due to leadedgasoline emissions ( $2.3 \mathrm{ng} / \mathrm{g}$; Table $\mathrm{S} 2$ in the supporting information). This again differs from Greenland where the Roman perturbation $(0.003 \mathrm{ng} / \mathrm{g})$ was 100 times lower than modern due to the wider distribution of more distal leaded-gasoline and other industrial emissions (McConnell et al., 2018).

In addition to the larger overall amplitude of the Roman perturbation in the Alps than in Greenland, another difference was that the first perturbation in the Alps (probably second- rather than third-century BCE) was about twice as high as the second (early second century CE), while in Greenland they were approximately equal (Figure 2a). FLEXPART simulations show that the Greenland NGRIP2 record was more equally sensitive to emissions ( 3 to $116\left(\mu \mathrm{g} \mathrm{m}^{2}\right.$ a)/(kg s)) from all pre-Roman and Roman-era mining sites (McConnell et al., 2018) compared to the CDD record (90 to 19,000 ( $\left.\mu \mathrm{g} \mathrm{m}^{2} \mathrm{a}\right) /(\mathrm{kg} \mathrm{s})$; Figure 3). This fivefold higher range in emission sensitivity in the Alpine record suggests that while the Greenland record largely reflected European-wide changes in emissions during antiquity, the Alpine record was more influenced by relatively close sources and that these nearby sources were relatively larger during the earlier perturbation, and probably during the early Middle Ages as well. Both Greenland and Alpine ice thus recorded rather large-scale lead pollution characterized during antiquity by two distinct phases of prosperity, the remote site of Greenland mirroring emissions from the whole of Europe, including southern Spain and Britain, whereas the high-elevation site of CDD recorded emissions reaching the free western European troposphere preferentially from countries like France and other Northern Mediterranean countries including Spain.

These large-scale ice records provide a complementary tool to lake sediments and peat bogs that are more intimately connected to regional emissions. As seen in Figures S1b-S1d in the supporting information most of these terrestrial and lacustrine records detected the Roman activities but with much poorer dating 

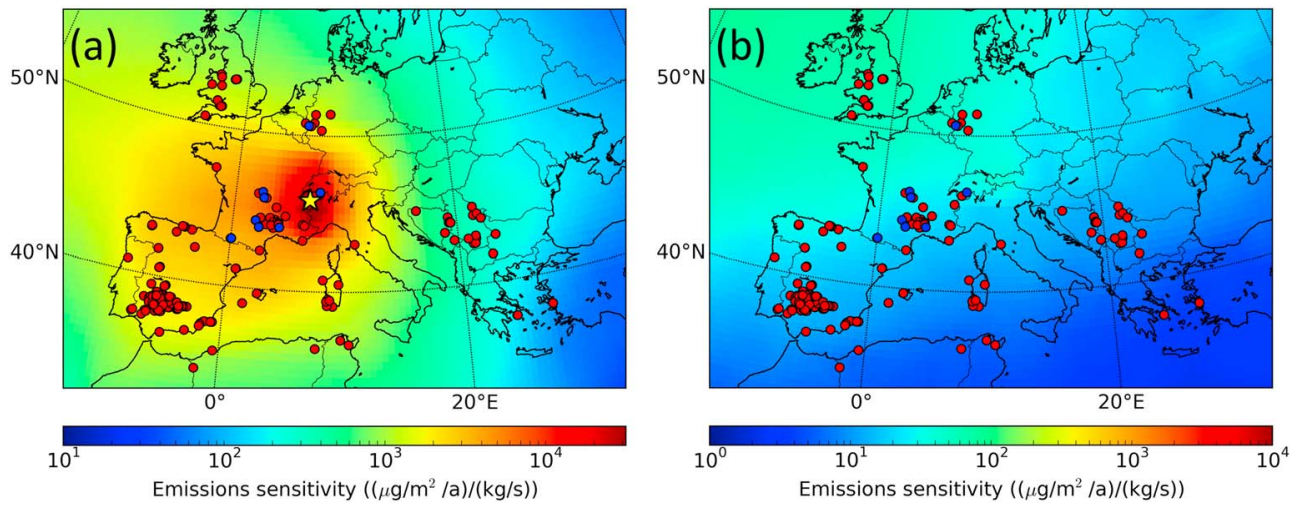

Figure 3. FLEXPART-simulated lead emissions sensitivities for the (a) CDD and (b) NGRIP2 (McConnell et al., 2018) ice core records (Text S4). Note the different color scales reflecting higher orders of magnitude for the CDD core. The location of the CDD drilling site is marked with a yellow star. Blue dots mark mines known to have been already active in the third to first centuries $\mathrm{BC}$ within an area of $500 \mathrm{~km}$ around CDD. Red dots mark all other Roman lead mines, that is, those close to CDD (i.e., $<500-\mathrm{km}$ distance), which were active mainly during the Imperial period, as well as all those further afield (Wilson \& Friedman, 2010).

compared to the unrivaled precision of the Greenland NGRIP 2 ice record, and with regional variability in peaks of emissions and their relative importance. As an example, whereas a 5 times larger lead perturbation during the Roman Republican period compared to the Roman Imperial period is recorded in an Alpine lake sediment (Figure S1a), a 2 times lower lead perturbation was observed during the midRoman Republican period compared to the Roman Imperial period in a peat bog from northern Spain (Figure S1d). These differences in the more local records of the two Roman periods, not seen in Greenland, are even larger than the factor of 2 observed at CDD.

The deepest part of the $\mathrm{CDD}$ record just above bedrock shows $\mathrm{Pb}$ and $\mathrm{Sb}$ levels comparable to those during the earlier Roman Republican period (second and third century BCE; Figure 2). Since these increases in $\mathrm{Pb}$ and $\mathrm{Sb}$ concentrations are accompanied by enhancements of the corresponding EF values (Figure S3), we cannot conclude that visible soil particles present in the basal ice are the cause of these increases. FLEXPART simulations (Figure 3) suggest that the CDD record was highly sensitive to emissions from Bronze Age mining and smelting operations in Austria (Lutz \& Pernicka, 2013). However, further studies from European glaciers and peat bogs, covering the entire Bronze Age, are here needed to confirm this finding.

\section{The Antimony Record in the CDK Basal Ice}

Of the metals investigated in this study (including, e.g., zinc, cadmium, vanadium, bismuth), only lead and antimony appear to be significantly reflective of Roman-era mining and smelting activities. Very few measurements of Sb in Alpine ice have been reported previously and none for antiquity (Text S3 and Table S2 in the supporting information). In addition, Sb was not measured in the NGRIP2 core from Greenland (McConnell et al., 2018) so the CDK record represents the first measurements of Sb levels in ice during antiquity (Figure $2 \mathrm{~b}$ ).

Similar to lead, background noncrustal Sb concentrations in CDK were low (0.0001-0.0005 ng/g) from 600 to $1,000 \mathrm{BCE}$ and 400 to $600 \mathrm{CE}$, with enhanced levels observed at $250 \mathrm{BCE}(0.0030 \mathrm{ng} / \mathrm{g})$ and $120 \mathrm{CE}$ $(0.0017 \mathrm{ng} / \mathrm{g})$. Enrichment factors $\left(\mathrm{Sb}-\mathrm{EF}_{\mathrm{Ce}}\right)$ of $\sim 1-3$ with respect to mean sediment (indicated by recovery-corrected cerium concentrations; Text S1) during these background periods suggest low levels of pollution. The $\mathrm{Sb} / \mathrm{Pb}$ ratio of 0.01 measured during the Roman period (Figure $2 \mathrm{~b}$ ) is consistent with values observed in a lead water pipe from Pompeii (79 CE; $\mathrm{Sb} / \mathrm{Pb}=0.0074$; Charlier et al., 2017). During the early Middle Ages, the CDK concentrations of ncSb rose more rapidly than those of $\mathrm{ncPb}$, leading to higher $\mathrm{ncSb} / \mathrm{ncPb}$ ratios (up to 0.038 at $780 \mathrm{CE}$ ) than during classical antiquity $(0.007 \pm 0.003)$. Such an increase in the $\mathrm{Sb} / \mathrm{Pb}$ anthropogenic ratio from prior to 500 to $~ 750 \mathrm{CE}$ also was observed in a Scottish peat core (Cloy et al., 2005). In this latter study it was proposed that this increase reflects the development of $\mathrm{Ag}$ mining in the Harz Mountains (Germany). 
The upper limit of nonpollution antimony in basal ice of CDK $(\sim 0.0003 \mathrm{ng} / \mathrm{g})$ is $6-10$ times lower than pollution during the Roman period, and 65 times lower than typical values $(\sim 0.02 \mathrm{ng} / \mathrm{g})$ observed in modern Alpine ice samples (Table S2) in the free European troposphere. As with lead, anthropogenic antimony emissions appear to have already been significant during the nineteenth century.

\section{Conclusions}

Measurements of ${ }^{14} \mathrm{C}$ in particulate organic matter in an ice core collected from a Mont Blanc glacier indicate that the basal ice is as old as $\sim 5,000( \pm 600)$ cal years BP and so the glacier potentially contains a record of heavy metal pollution during European antiquity. Such a record, developed using continuous measurements of lead, antimony, and cerium in ice from the deepest $10 \mathrm{~m}$ of the glacier, suggests that lead and antimony pollution were closely linked. The large, century-long increases in atmospheric $\mathrm{Sb}$ and $\mathrm{Pb}$ emissions coincided with the known pre-Roman and Roman-era mining and smelting operations. The Roman-era perturbation in CDD lead levels is larger than in Greenland, by a factor of 100 during the late Iron Age or middle Roman Republican period (i.e., probably $140 \mathrm{BCE}$ ) and a factor of 50 during the Roman Empire. Differences between the Greenland and Alpine ice records, underpinned by FLEXPART model simulations of emissions sensitivities for the two sites, show that proximal European records of pollution, and thus of mining and smelting activities during antiquity, may be more strongly influenced by nearby emissions. This first ice record of antimony pollution during antiquity, showing large Roman-era increases by a factor of 6-10 in parallel with lead (a factor of 15-30) with respect to background levels, confirms that early mining and smelting activities had environmental implications beyond just lead contamination.

\section{Acknowledgments}

The drilling operation to extract the CDK ice core at Col du Dome was supported by the EU CARBOSOL project (contract EVK2 CT2001-00113, EVK2-2001-00067). We thank all colleagues, which participated in the drilling field campaigns at $\mathrm{Col}$ du Dome in 2004. We thank the two anonymous reviewers for very useful comments, which significantly improved the quality of the manuscript. Col du Dome ice core data and FLEXPART model results presented in this paper are available as supporting dataset (Preunkert-ds01.xlsx and Preunkertds02.xlsx).

\section{References}

Bindler, R. (2018). Comment on "Next-generation ice Core technology reveals true minimum natural levels of lead (Pb) in the atmosphere: Insights from the black death" by More et al. GeoHealth, 2(5), 155-161. https://doi.org/10.1002/2018GH000135

Blanchard, I. (2001). Mining, Metallurgy and Minting in the Middle Ages (781 p.). Stuttgart, Germany: Franz Steiner. https://doi.org/ $10.1017 / \mathrm{S} 0395264900036374$

Bowen, H. (1966). Trace Elements in Biochemistry. New York: Academic Press.

Brännvall, M.-L., Bindler, R., Emteryd, O., \& Renberg, I. (2001). Four thousand years of atmospheric lead pollution in northern Europe: A summary from Swedish lake sediments. Journal of Paleolimnology, 25(4), 421-435. https://doi.org/10.1023/ A:1011186100081

Bronk Ramsey, C. (1995). Radiocarbon calibration and analysis of stratigraphy: The OxCal program. Radiocarbon, 37(02), 425-430. https:// doi.org/10.1017/s0033822200030903

Charlier, P., Bou Abdallah, F., Bruneau, R., Jacqueline, S., Augias, A., Bianucci, R., et al. (2017). Did the Romans die of antimony poisoning? The case of a Pompeii water pipe (79 CE). Toxicology Letters, 281, 184-186. https://doi.org/10.1016/j.toxlet. 2017.07.876

Cloy, J. M., Farmer, J. G., Graham, M. C., MacKenzie, A. B., \& Cook, G. T. (2005). A comparison of antimony and lead profiles over the past 2500 years in Flanders Moss ombrotrophic peat bog, Scotland. Journal of Environmental Monitoring, 7(12), 1137-1147. https://doi.org/ 10.1039/b510987f

Gabrieli, J., \& Barbante, C. (2014). The Alps in the age of the Anthropocene: The impact of human activities on the cryosphere recorded in the Colle Gnifetti glacier. Rendiconti Lincei, 25(1), 71-83. https://doi.org/10.1007/s12210-014-0292-2

Gabrielli, P., Barbante, C., Bertagna, G., Bertó, M., Binder, D., Carton, A., et al. (2016). Age of the Mt. Ortles ice cores, the Tyrolean Iceman and glaciation of the highest summit of South Tyrol since the Northern Hemisphere Climatic Optimum. The Cryosphere, 10(6), 2779-2797. https://doi.org/10.5194/tc-10-2779-2016

Haeberli, W., \& Alean, J. (1985). Temperature and accumulation of high altitude firn in the Alps. Annals of Glaciology, 6, 161-163. https:// doi.org/10.3189/1985aog6-1-161-163

Hoffmann, H., Friedrich, R., Kromer, B., \& Fahrni, S. (2017). Status report: Implementation of gas measurements at the MAMS 14 C AMS facility in Mannheim, Germany. Nuclear Instruments and Methods in Physics Research Section B: Beam Interactions with Materials and Atoms, 410, 184-187. https://doi.org/10.1016/j.nimb.2017.08.018

Hoffmann, H., Preunkert, S., Legrand, M., Leinfelder, D., Bohleber, P., Friedrich, R., \& Wagenbach, D. (2018). A new sample preparation system for micro- ${ }^{14} \mathrm{C}$ dating of glacier ice with a first application to a high alpine ice core from Colle Gnifetti (Switzerland). Radiocarbon, 60(02), 517-533. https://doi.org/10.1017/rdc.2017.99

Jenk, T., Szidat, S., Bolius, D., Sigl, M., Gäggeler, H., Wacker, L., et al. (2009). A novel radiocarbon dating technique applied to an ice core from the Alps indicating late Pleistocene ages. Journal of Geophysical Research, 114, D14305. https://doi.org/10.1029/ 2009JD011860

Jenk, T., Szidat, S., Schwikowski, M., Gäggeler, H., Brütsch, S., Wacker, L., et al. (2006). Radiocarbon analysis in an alpine ice core: Record of anthropogenic and biogenic contributions to carbonaceous aerosols in the past (1650-1940). Atmospheric Chemistry and Physics, 6(12), 5381-5390. https://doi.org/10.5194/acp-6-5381-2006

Legrand, M., McConnell, J., Preunkert, S., Arienzo, M., Chellman, N., Gleason, K., et al. (2018). Alpine ice evidence of a three-fold increase in atmospheric iodine deposition since 1950 in Europe due to increasing oceanic emissions. Proceedings of the National Academy of Sciences, 115(48), 12,136-12,141. https://doi.org/10.1073/pnas.1809867115

Legrand, M., Preunkert, S., May, B., Guilhermet, J., Hoffman, H., \& Wagenbach, D. (2013). Major 20th century changes of the content and chemical speciation of organic carbon archived in Alpine ice cores: Implications for the long-term change of organic aerosol over Europe. Journal of Geophysical Research: Atmospheres, 118, 3879-3890. https://doi.org/10.1002/jgrd.50202 
Legrand, M., Preunkert, S., Schock, M., Cerqueira, M., Kasper-Giebl, A., Afonso, J., et al. (2007). Major 20th century changes of carbonaceous aerosol components (EC, WinOC, DOC, HULIS, carboxylic acids, and cellulose) derived from Alpine ice cores. Journal of Geophysical Research, 112, D23S11. https://doi.org/10.1029/2006JD008080

Loveluck, C., McCormick, M., Spaulding, N., Clifford, H., Handley, M., Hartman, L., et al. (2018). Alpine ice-core evidence for the transformation of the European monetary system, AD 640-670. Antiquity, 92(366), 1571-1585. https://doi.org/10.15184/ aqy.2018.110

Lüthi, M., \& Funk, M. (2000). Dating ice cores from a high alpine glacier with a flow model for cold firn. Annals of Glaciology, 31, 69-79. https://doi.org/10.3189/172756400781820381

Lutz, J., \& Pernicka, E. (2013). Prehistoric copper from the eastern Alps. Open Journal of Archaeometry, 1(1), 25. https://doi.org/10.4081/ arc.2013.e25

Maselli, O., Chellman, N., Grieman, M., Layman, L., McConnell, J., Pasteris, D., et al. (2017). Sea ice and pollution-modulated changes in Greenland ice core methanesulfonate and bromine. Climate of the Past, 13(1), 39-59. https://doi.org/10.5194/cp-13-39-2017

McConnell, J., Aristarain, A., Banta, J., Edwards, P., \& Simoes, J. (2007). 20th-century doubling in dust archived in an Antarctic Peninsula ice core parallels climate change and desertification in South America. Proceedings of the National Academy of Sciences, 104(14), 5743-5748. https://doi.org/10.1073/pnas.0607657104

McConnell, J., \& Edwards, R. (2008). Coal burning leaves toxic heavy metal legacy in the Arctic. Proceedings of the National Academy of Sciences, 105(34), 12,140-12,144. https://doi.org/10.1073/pnas.0803564105

McConnell, J., Wilson, A., Stohl, A., Arienzo, M., Chellman, N., Eckhardt, S., et al. (2018). Lead pollution recorded in Greenland ice indicates European emissions tracked plagues, wars, and imperial expansion during antiquity. Proceedings of the National Academy of Sciences, 115(22), 5726-5731. https://doi.org/10.1073/pnas.1721818115

More, A. F., Spaulding, N. E., Bohleber, P., Handley, M. J., Hoffmann, H., Korotkikh, E. V., et al. (2017). Next generation ice core technology reveals true minimum natural levels of lead $(\mathrm{Pb})$ in the atmosphere: Insights from the black death. GeoHealth, 1, 211-219. https://doi.org/10.1002/2017GH000064

Nriagu, J. (1989). A global assessment of natural sources of atmospheric trace metals. Nature, 338(6210), 47-49. https://doi.org/10.1038/ $338047 \mathrm{a} 0$

Preunkert, S., \& Legrand, M. (2013). Towards a quasi-complete reconstruction of past atmospheric aerosol load and composition (organic and inorganic) over Europe since 1920 inferred from alpine ice cores. Climate of the Past, 9(4), 1403-1416. https://doi.org/10.5194/cp-91403-2013

Preunkert, S., Wagenbach, D., Legrand, M., \& Vincent, C. (2000). Col du Dôme (Mt Blanc Massif, French Alps) suitability for ice-core studies in relation with past atmospheric chemistry over Europe. Tellus B: Chemical And Physical Meteorology, 52(3), 993-1012. https:// doi.org/10.3402/tellusb.v52i3.17081

Reimer, P. J., Bard, E., Bayliss, A., Beck, J. W., Blackwell, P. G., Bronk Ramsey, C., et al. (2013). IntCal13 and Marine13 radiocarbon age calibration curves 0-50,000 years cal BP. Radiocarbon, 55(04), 1869-1887. https://doi.org/10.2458/azu_js_rc.55.16947

Rosman, K., Chisholm, W., Hong, S., Candelone, J., \& Boutron, C. (1997). Lead from Carthaginian and Roman Spanish mines isotopically identified in Greenland ice dated from 600 BC to 300 AD. Environmental Science \& Technology, 55(04), 1869-1887. https://doi.org/ $10.1021 / \mathrm{es} 970038 \mathrm{k}$

Schwikowski, M. (2004). Reconstruction of European air pollution from alpine ice cores. In L. D. Cecil, J. R. Green, \& L. G. Thompson (Eds.), Earth Palaeoenvironments: Records Preserved in Mid- and Low-Latitude Glaciers (pp. 95-119). Dordrecht: Kluwer Academic Publishers. https://doi.org/10.1007/1-4020-2146-1_6

Sigl, M., Jenk, T. M., Kellerhals, T., Szidat, S., Gäggeler, H. W., Wacker, L., et al. (2009). Towards radiocarbon dating of ice cores. Journal of Glaciology, 55(194), 985-996. https://doi.org/10.3189/002214309790794922

Stohl, A., Forster, C., Frank, A., Seibert, P., \& Wotawa, G. (2005). Technical note: The Lagrangian particle dispersion model FLEXPART version 6.2. Atmospheric Chemistry and Physics, 5(9), 2461-2474. https://doi.org/10.5194/acp-5-2461-2005

Thevenon, F., Guédron, S., Chiaradia, M., Loizeau, J., \& Poté, J. (2011). (Pre-) historic changes in natural and anthropogenic heavy metals deposition inferred from two contrasting Swiss alpine lakes. Quaternary Science Reviews, 30(1-2), 224-233. https://doi.org/10.1016/j. quascirev.2010.10.013

Vincent, C., Vallon, M., Pinglot, J., Funk, M., \& Reynaud, L. (1997). Snow accumulation and ice flow at Dôme du Goûter (4300 m), Mont Blanc, French Alps. Journal of Glaciology, 43(145), 513-521. https://doi.org/10.3189/s0022143000035127

Wagenbach, D., Bohleber, P., \& Preunkert, S. (2012). Cold, alpine ice bodies revisited: What may we learn from their impurity and isotope content? Geografiska Annaler: Series A, Physical Geography, 94(2), 245-263. https://doi.org/10.1111/j.1468-0459.2012.00461.x

Wagenbach, D., Münnich, K., Schotterer, U., \& Oeschger, H. (1988). The anthropogenic impact on snow chemistry at Colle Gnifetti, Swiss Alps. Annals of Glaciology, 10, 183-187. https://doi.org/10.1017/S0260305500004407

Wilson, A., \& Friedman, H. (2010). Mining database. Version 1.0. Available at oxrep.classics.ox.ac.uk/databases/mines_database/. Accessed December 15, 2018: http://oxrep.classics.ox.ac.uk/databases/mines_database/

\section{References From the Supporting Information}

Barbante, C., Schwikowski, M., Doring, T., Gaggeler, H. W., Schotterer, U., Tobler, L., et al. (2004). Historical record of European emissions of heavy metals to the atmosphere since the 1650 s from alpine snow/ice cores drilled near Monte Rosa. Environmental Science \& Technology, 38(15), 4085-4090. https://doi.org/10.1021/es049759r

Bindler, R., Brännvall, M.-L., Renberg, I., Emteryd, O., \& Grip, H. (1999). Natural lead concentrations in pristine boreal forest soils and past pollution trends: A reference for critical load models. Environmental Science \& Technology, 33(19), 3362-3367. https://doi.org/10.1021/ es9809307

Eckhardt, S., Cassiani, M., Evangelious, N., Sollum, E., Pisso, I., \& Stohl, A. (2017). Source-receptor matrix calculation for deposited mass with the Lagrangian particle dispersion model FLEXPART v10.2 in backward mode. Geoscientific Model Development, 10(12), 4605-4618. https://doi.org/10.5194/gmd-10-4605-2017

Gilbert, A., Gagliardini, O., Vincent, C., \& Wagnon, P. (2014). A 3-D thermal regime model suitable for cold accumulation zones of polythermal mountain glaciers. Journal of Geophysical Research: Earth Surface, 119, 1876-1893. https://doi.org/10.1002/2014JF003199

Laloyaux, P., de Boisseson, E., \& Dahlgren, P. (2017). CERA-20C: An Earth system approach to climate reanalysis. ECMWF Newsletter, 150 , 25-30. https://www.ecmwf.int/node/18164. https://doi.org/10.21957/ffs36birj2 
Le Roux, G., Weiss, D., Grattan, J. P., Givelet, N., Krachler, M., Cheburkin, A., et al. (2004). Identifying the sources and timing of ancient and medieval atmospheric lead pollution in England using a peat profile from Lindow bog, Manchester. Journal of Environmental Monitoring, 39(3), 717-727. https://doi.org/10.1016/j.jas.2011.10.037

Martínez Cortizas, A., García-Rodeja, E., Pontevedra Pombal, X., Nóvoa Muñoz, J., Weiss, D., \& Cheburkin, A. (2002). Atmospheric Pb deposition in Spain during the last 4600 years recorded by two ombrotrophic peat bogs and implications for the use of peat as archive. Science of the Total Environment, 292(1-2), 33-44. https://doi.org/10.1016/s0048-9697(02)00031-1

Millard, A. (2014). Conventions for reporting radiocarbon determinations. Radiocarbon, 56(02), 555-559. https://doi.org/10.1017/ s0033822200049596

Nye, J. (1963). Correction factor for accumulation measured by the thickness of the annual layers in an ice sheet. Journal of Glaciology, 4(36), 785-788. https://doi.org/10.3189/s0022143000028367

Schwikowski, M., Barbante, C., Doering, T., Gaeggeler, H., Boutron, C., Schotterer, U., et al. (2004). Post-17th-century changes of European lead emissions recorded in high-altitude alpine snow and ice. Environmental Science \& Technology, 38(4), 957-964. https://doi.org/ $10.1021 / \mathrm{es} 0347150$

Seibert, P., \& Frank, A. (2004). Source-receptor matrix calculation with a Lagrangian particle dispersion model in backward mode Atmospheric Chemistry and Physics, 4(1), 51-63. https://doi.org/10.5194/acp-4-51-2004

Van de Velde, K., Ferrari, C., Barbante, C., Moret, I., Bellomi, T., Hong, S., \& Boutron, C. (1999). A 200 year record of atmospheric cobalt, chromium, molybdenum, and antimony in high altitude alpine firn and ice. Environmental Science \& Technology, 33(20), 3495-3501. https://doi.org/10.1021/es990066y 